\title{
Perceptions of On-Premise Commercial Sign Regulation Codes for Beauty, Interest, and Order by Designers and Non-Designers
}

\section{Maleah Rakestraw}

Environmental Designer

Williams \& Works Engineering,

Grand Rapids, MI

rakestraw@williams-works.com

\author{
Pat Crawford* \\ Professor and Director \\ School of Design, \\ South Dakota State University, \\ Brookings, SD
}

pat.crawford@sdstate.edu

\section{Eunsil Lee}

\author{
Associate Professor \\ School of Planning, \\ Design \& Construction, \\ Michigan State University. \\ East Lansing, MI
}

leeeunsi@msu.edu

\section{INTRODUCTION}

The urban landscape is comprised of many parts, all regulated by a municipal code. One of these parts, signage, is an important element within the urban environment, as both way-finding and commercial signs line modern American streets (Meikle, 2013). Their primary function is communication, and they are regulated by a municipality's code or ordinance to protect the health, safety, and general welfare of the public (Strauss, Jourdan, \& Weinstein, 2014; Jourdan, Hurd, \& Hawkins, 2013). A signscape, the collection of signs within a streetscape, can have a pronounced effect on the socio-economic productivity of a place (Rexhausen, Hildebrandt, \& Auffrey, 2012; Stotmeister, 2013; Taylor, Sarkees, \& Bang, 2012; Alford, 2011). A legible and well organized signscape can increase positive perception and economic activity while the opposite can lead to visual pollution and can hinder economic activity.

Regulation development has long been an area of contempt for designers and for whom they design (Pendlebury \& Townshend, 1999; Kaplan \& Kaplan, 1989). Public involvement in planning has become increasingly prevalent (Lane, 2005; Sanoff, 2000), so now, more important than ever, design professionals and non-designers must successfully create effective regulations collaboratively to advance urban growth and development. It would seem as though the education and training planning and design professionals receive would alter their perception of the urban landscape, but there is conflicting evidence on whether or not this perception varies much from non-designers (Portella, 2014; Yung \& Chan, 2013; Gjerde, 2011; Pugalis, 2009; Coeterier, 2002; Kaplan \& Kaplan, 1989). If these two groups do not perceive the environment similarly, it can be argued that planning and design professionals would have difficulty providing their clients with products that accurately represent their wants and needs. Understanding how each group thinks and

\section{Abstract /}

Regulation has long since guided urban growth, and it is essential for municipalities to construct regulation that is conducive to creating visually stimulating public spaces. Minimal scientific research has been conducted on the impacts of commercial signage and the varying arrangements created by different sign regulations in regard to perception (Jourdan, Hurd, \& Hawkins, 2013; Portella, 2014). With the rise of public involvement in planning (Lane, 2005; Sanoff, 2000), it is essential that designers and non-designers coordinate to develop sign controls that contribute to urban growth. This research studies the differences and similarities in perceptions of planning and design professionals and non-designers to aid in the development of future, more positively perceived, signage regulation. By using visual models presented in the form of a survey, findings show both similarities and differences between these groups in their assessment of signscapes regarding communication, perceptions of characteristics like beauty, interest, and order, an overall preference toward highly structured codes, and a difference in harshness of evaluation.

\section{Keywords /}

on-premise signage; zoning code; formbased code; perceptions of designers and non-designers 
communicates is a first step in effectively creating a collaborative environment for urban signage development.

Existing research has found the quantity, placement, design, and size of commercial signage can contribute to visual clutter and has the potential to decrease the aesthetic quality of the outdoor environment (Jourdan, Hurd, \& Hawkins, 2013; Portella, 2014). Because of the impact that signage can have on the public realm (Crawford, Lee, \& Beatty, 2015; Berger, 2014; Portella, 2014; Nasar \& Hong, 1999), proper regulation of these structures is key to creating visually stimulating public spaces. In connecting environmental perception and signage, it is apparent that a gap in research exists between how designers and non-designers consider on-premise commercial sign regulation.

The purpose of this interpretive study is to understand how the perceptions of designers and non-designers are similar and differ regarding on-premise commercial sign controls within urban corridors. The area of research is in the greater Lansing, Michigan area, and focuses specifically on a span of Michigan Avenue that extends over two municipalities, the cities of Lansing and East Lansing. By understanding the perceptions of on-premise sign controls by different user groups in this localized policy environment, this study can add to the body of knowledge regarding sign regulation and design.

\section{LITERATURE REVIEW}

\section{Designers and Non-Designers}

Challenges in public planning can arise from miscommunication between designers and non-designers. The public often has difficulty describing their requests and requirements regarding development, resulting in a fixation on specific details instead of the exploration of broad ideas (Kaplan \& Kaplan, 1989). Conversely, designers may overwhelm the public with project's complicated technical aspects (Creighton, 2005). This gap in communication, along with the presence of multiple individual desires and preferences, makes it particularly challenging to cultivate productive conversations concerning planning and development (Kaplan \&Kaplan, 1989; Burisch, 1979), but, as Sanoff(2000) notes, individuals can be reasonable and capable of altering their views when presented with new information and a shared vision.

Designers, among others, are responsible for shaping the public realm and guiding the development of signage including theme, regulation, construction, placement, and form. Historically, expert opinion has been used as the primary source for developing city regulations (Portella, 2014; Pugalis, 2009; Parolek, Parolek, \& Crawford, 2008). The debate on how heavily to rely on expert opinion is based principally on the idea of the expert's understanding of regulation and how that can truly represent community desires. However, differences in perception exist between designers and non-designers and designers may only have a limited ability to predict public preferences (Kaplan \& Kaplan, 1989). Research confirms that facets of the outdoor environment, such as architecture, historic sites, and civic spaces, are evaluated differently by designers and non-designers (Yung \& Chan, 2013; Pugalis, 2009; Coeterier, 2002; Kaplan \& Kaplan, 1989).

Notable environmental perception studies found differences between designers and non-designers in perception of the outdoor environment (Pugalis, 2009; Coeterier, 2002). The studies had conflicting results of evaluation criteria considered as significant to each group. In Pugalis' (2009) study of urban public space, research found that designers were predominantly concerned with the aesthetics of urban public space while non-designers found social encounters and cultural experiences within the space to be more important. Conversely, in research on the evaluation of historic sites, Coeterier (2002) reported that non-designers were more concerned with physical form or aesthetics while design professionals concentrated on features such as building age, rarity, and completeness. This variability may result from the different subject matter under evaluation; the discrepancies between how designers and non-designers evaluate environments remains.

While there is considerable support for the claim that designers and non-designers perceive environments differently, the degree of these differences is not well defined. Several studies observed similarities, as well as differences, between evaluation criteria of designers 
and non-designers (Yung \& Chan, 2013; Pugalis, 2009; Coeterier, 2002). Yung and Chan (2013) and Gjerde (2011) indicate that professionals and non-designers evaluate spaces slightly differently and allude to statistically significant differences in perception between the two groups. However the research indicated that these dissimilarities may not be substantial. Studying social, economic, and aesthetic variables, one case found that both designers and non-designers identified architectural merit as significant for evaluating historic buildings. Although this variable was identified as significant by both groups, architectural merit was the most significant criteria to non-designers, while cultural identity was ranked first by built environment professionals (Yung \& Chan, 2013).

Gjerde (2011) also found that designers and non-designers perceive urban street scenes similarly. Significant differences were not found in perception, but rather in the greater conviction with which designers voiced their thoughts in contrast to non-designers. While previous research comparing perceptions commonly focused on singular objects or buildings, Gjerde (2011) speculated that by studying the urban environment as a whole, similarities between these two groups may be more apparent.

In her book Visual Pollution, Portella (2014) found commonalities across designers and non-designers. These conclusions are consistent with Crawford, et al. (2015), where thirteen stakeholder groups, including planning / design professionals, were compared. While these results vary from some of the literature, both Portella (2014) and Crawford, et al. (2015) measure the perceptions of planning and design professionals in relation to commercial sign controls. These studies also focused on streetscape evaluation; because the outdoor environment is complex, signscapes could be a distinct variable that is evaluated similarly by both designers and non-designers.

\section{On-Premise Signage and Regulation}

On-premise commercial signs are signs located on the site of the business for which the sign advertises (Kieffer, 2001). This includes, but is not limited to, building mounted signs, electronic message centers, pole signs, pylons, roof signs, animated signs, ground signs, and window signs. Wayfinding signs direct users to a given destination and include traffic, street, and directional signs (Kieffer, 2001). Because on-premise commercial signs are located on private property, they offer their own sets of challenges regarding traffic and safety. Understanding sign characteristics that provide motorists with clear communication, thereby ensuring safety, is a contributing factor to the regulation of on-premise signs (Garvey \& Crawford, 2015; Jourdan et al., 2013).

Misguided regulation of on-premise commercial signage occurs because of a misunderstanding of the impact that signs have on the visual landscape and the economic welfare of a business (Taylor, 2011). Since the early 1900s, sign regulation has been allowed, grounded on the ideas that regulations protect community health, safety, and general welfare (Jourdan et al., 2013). Sign controls are traditionally governed by a municipality's zoning ordinance, however alternative forms of sign controls can be found in other municipal regulations, like form-based codes (Parolek et al., 2008). Zoning regulations rely on a distinct separation of uses and these types of regulations have been criticized for their tendency to hinder business development (Liebermann, 2002; Parolek et al., 2008). For example, signage regulations within zoning codes define specific requirements regarding height, luminosity, sign type, placement, and other aspects (Jourdan et al., 2013). The objective for both a zoning and form-based code is to organize signage in a way that promotes health, safety, and general welfare, but modern sign policies may be overreaching from their original scope, as sign regulation is often based on localized aesthetic preferences and not empirical health, safety, and welfare research (Strauss et al., 2014; Jourdan et al., 2013; Kinoshita \& Orlando, 2013; Taylor, 2006).

For the first time since World War II, urban centers in the United States are growing, increasing the demand for high density, multiuse structures and spaces that can be difficult to accommodate with traditional zoning regulation (Cohen et al., 2015; Liebermann, 2002; United States Department of Agriculture, 2015). Form-based codes emerged as an alternative to traditional zoning, forming a regulatory relationship between the built and natural environment to encourage economic growth and combat urban sprawl through sustainable, walkable, and high-quality environments 
(Parolek et al., 2008). These ideals are traditional components in streetscape design but have only recently regained broad support from urban planners and designers (Parolek et al., 2008). Form-based codes consist of graphic or typological coding. The rules are described with simple text accompanied by clearly drawn diagrams, definitions, and additional visuals that support the character to be created by each specific code (Form-Based Codes Institute Staff, 2013). This approach makes form-based codes user-friendly and act as guides for designing commercial signage (FormBased Codes Institute Staff, 2013; Parolek et al., 2008).

Research indicates that urban streetscapes can be improved by reducing sign obtrusiveness (Nasar \& Hong, 1999). In this study, respondents preferred less-obtrusive signscapes, finding the signs to be more legible and viewed these places as more interesting and desirable to visit (Nasar \& Hong, 1999). Other research (see www. signresearch.org) found that signage located in urban downtowns was positively perceived when high resolution digital and backlight signs were present and signscape was diverse (Berger, 2014).

\section{Signage and Communication}

An unchanging aspect within the study of signage perception regards the primary function that signs provide-communication. In nearly all of the literature reviewed, a positive correlation between sign communication and legibility exists (Portella, 2014; Berger, 2014; Nasar \& Hong, 1999; Vanderbona \& Yossayaffra, 1999; Werner \& Kaminoff, 1983). In addition to increasing efficiency of directional movement (Bai et al., 2010), clear signage can have a positive impact on perceived crowding and reduce feelings of confusion (Werner \& Kaminoff, 1983). This reinforces the justification for controls that regulate sign placement, scale, and organization.

Portella (2014) studied perceptions of commercial signage in historic downtowns across cultures in search of universal or distinct preferences. This research analyzed advertising, signage, and environmental quality and began to define factors of beauty, interest, and order that support an aesthetic signscape. It also found common perceptions of signage across cultures and professions, as well as an increased positive perception for historic city centers with sign regulations in place. Consistent with Portella (2014), Crawford et al. (2015) studied stakeholder perceptions of commercial sign controls, finding common perceptions of signage regulations in non-historic areas. Both Portella (2014) and Crawford et al. (2015) identified connections between user preference and sign controls, providing a foundation for future research.

\section{Research Opportunity}

The main themes of the literature review point towards opportunities for research. Signage provides a common function of communication across users of the environment. Many users are non-designers, and there are differences in how designers and non-designers perceive signage. Commercial sign regulations and policies influence signage design and the aesthetic aspects of perceived beauty, interest, and order.

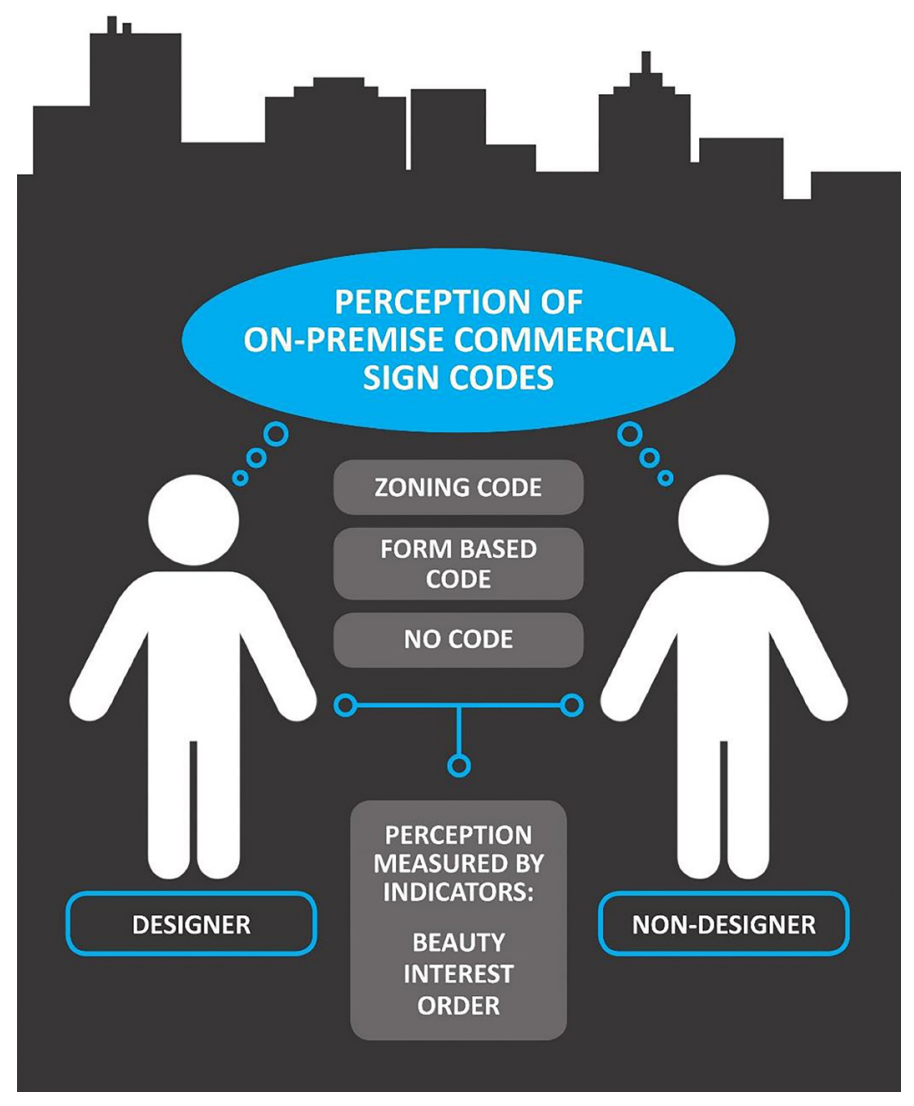

Figure 1 / Conceptual Framework

\section{METHODS \\ Conceptual Framework}

The study considers perception of on-premise com- 
mercial sign codes by designers with professional training in the field and non-designers. Three signage code formats were studied: zoning code, formbased code, and no code; beauty, interest, and order are the indicators used to measure user perceptions (see Figure 1). The aesthetic indicators are drawn from Portella's (2014) research and measured using a five-point Likert scale. Working definitions for the indicators are:

1. Beauty: Qualities of physical form evoking a positive response or feeling correlated to attractiveness.

2. Interest: A visually stimulating character that activates and engages the senses.

3. Order: The harmonious arrangement of parts in a consistent or rhythmic pattern.

\section{Research Question}

The central research question is: Are there differences in perception of on-premise commercial sign regulations between designers and non-designers? A series of associated sub-questions have been developed to supplement the central research question:

$\mathrm{RQ}_{1}$ : Is there a significant difference in perception of beauty, interest, and order in the no code sign models between designers and non-designers?

$\mathrm{RQ}_{2}$ : Is there a significant difference in perception of beauty, interest, and order in the zoning code sign models between designers and non-designers?

$\mathrm{RQ}_{3}$ : Is there a significant difference in perception of beauty, interest, and order in the form- based code sign models between designers and non-designers?

\section{Research Site}

The study area is a three-mile section of the Grand River/Michigan Avenue corridor connecting Michigan State University and the Michigan Capitol, with

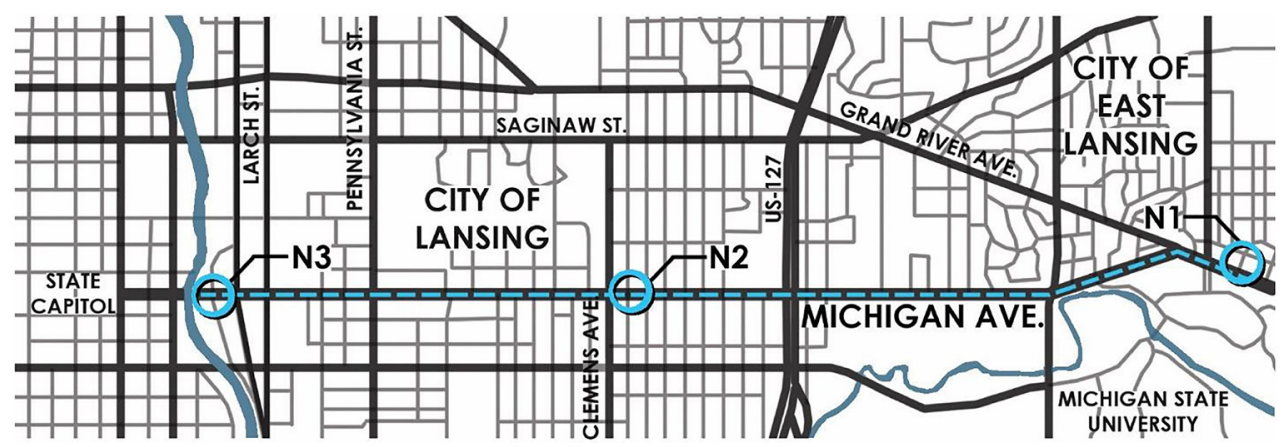

Figure 2 / Greater Lansing Research Site and Study Nodes

\footnotetext{
${ }^{1}$ Details regarding the research site, model development and study node images are cited with permission from Current Urban Studies (see Appendix A) from the 2015 publication, "Aesthetic perception of urban streetscapes and the impact of form-based codes and traditional zoning codes on commercial signage," by Crawford, Lee, and Beatty.
} 

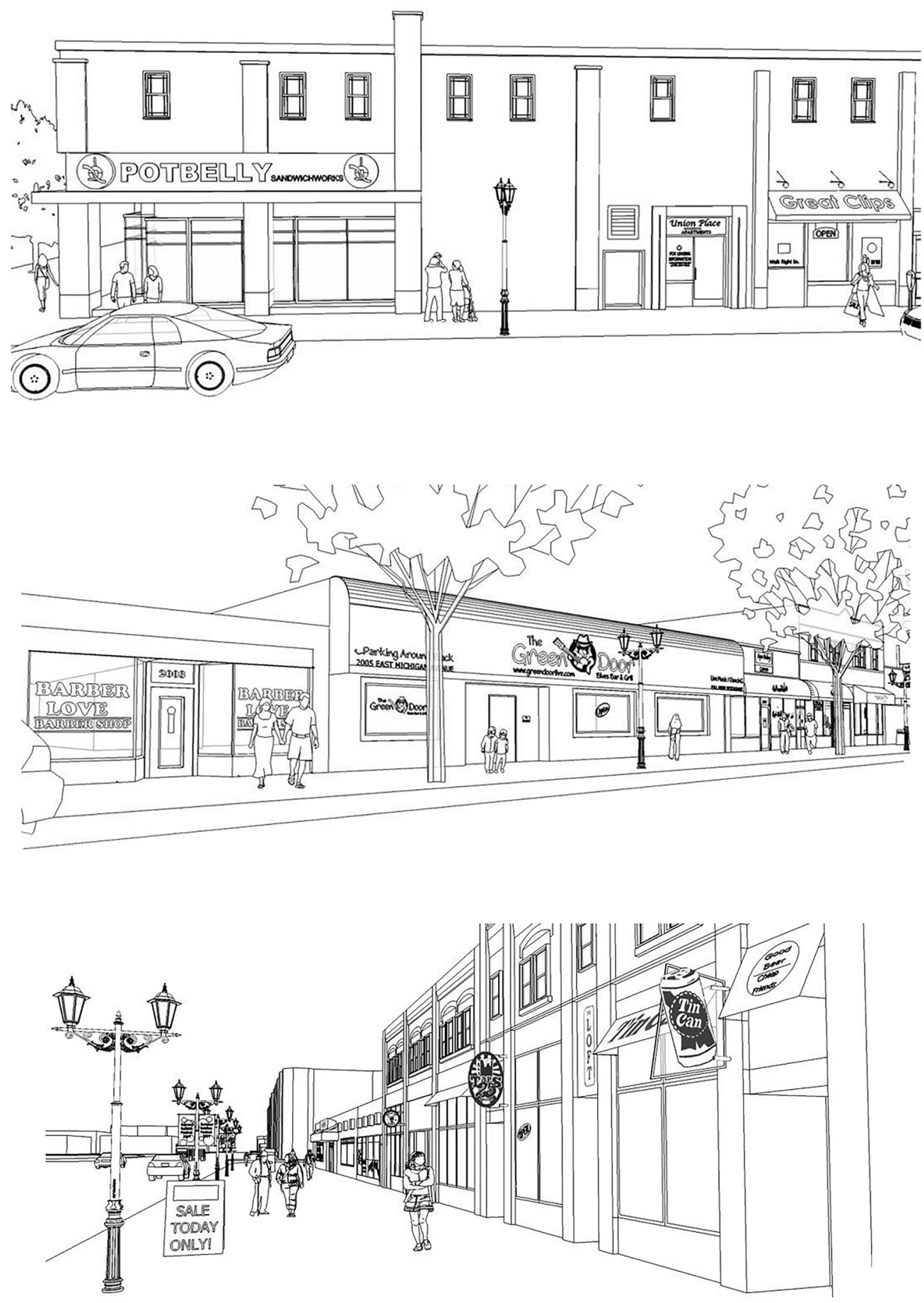

three specified locations identified as the focus (see Figure 2) ${ }^{1}$. Graphic images of the current signage code application are represented in Figures 3, 4, and 5. The node images in Figures 3, 4, and 5 were generated to show the signage in the clearest perspective possible are depending on sign size and mounting. The variations of image vantage point are potentially a study limitation.

\section{Research Design}

This study uses an in-situ approach to studying the perceptions of designers and non-designers, where the three nodes along Michigan Avenue are modified
Figure 3 / Node 1: East Lansing

Existing Conditions

Figure 4 / Node 2: Lansing East Michigan Avenue Existing Conditions

Figure 5 / Node 3: Downtown Lansing Existing Conditions 
from their original state to create new models with altered sign code applications. The research design enables statistical data to be collected through a predefined online survey.

\section{Study Node Model Development}

To gauge the perceptions of respondents, the survey used digital models to prompt responses. Participants were asked to rate six streetscape models based on the three aesthetic indicators. Two models were created for each of the three study nodes using the current zoning code, a form-based code, or a no code sign application, producing six images in total. These streetscapes were created using SketchUp, a 3D modeling program, which produced a valid tool to gauge participant environmental perceptions (Partin, 2011). The black-and-white line drawing models follow Partin's (2011) research, which found consistent evaluations by non-designers between the computer-generated drawings and photos of the same site. Color was intentionally eliminated to provide consistency across the sites and remove color bias; this is a study limitation and provides an avenue for future study.

Each streetscape was rated by participants on three, five-point Likert scales that separately measured beauty, interest, and order. The question reads, "Rate the streetscape along each of the following scales" and response options are:

Scale 1: very beautiful, beautiful, neutral, ugly, very ugly

Scale 2: very boring, boring, neutral, interesting, very interesting

Scale 3: very ordered, ordered, neutral, chaotic, very chaotic

The sign code applications used to develop the model images were based on the existing zoning sign code in Lansing and the form-based code of Casper, Wyoming. By using existing streetscapes with existing codes, the study could ensure that when developing the model images codes were accurately applied. Casper's Old Yellowstone District form-based code was chosen to guide the design of the alternative form-based code models because of the city's comparable size to Lansing and the established application of signage code on a downtown streetscape. The no code sign application was developed by using only non-conforming signs under existing sign regulations.

Detailed descriptions of each model development are illustrated below:

\section{Node 1- East Lansing}

Signage in Node 1 is governed by East Lansing's zoning code as a " $\mathrm{C}$ parcel." Two streetscape models for Node 1 were created: The zoning code sign model, representative of existing conditions, and an alternative no code sign model (see Figure 6). 


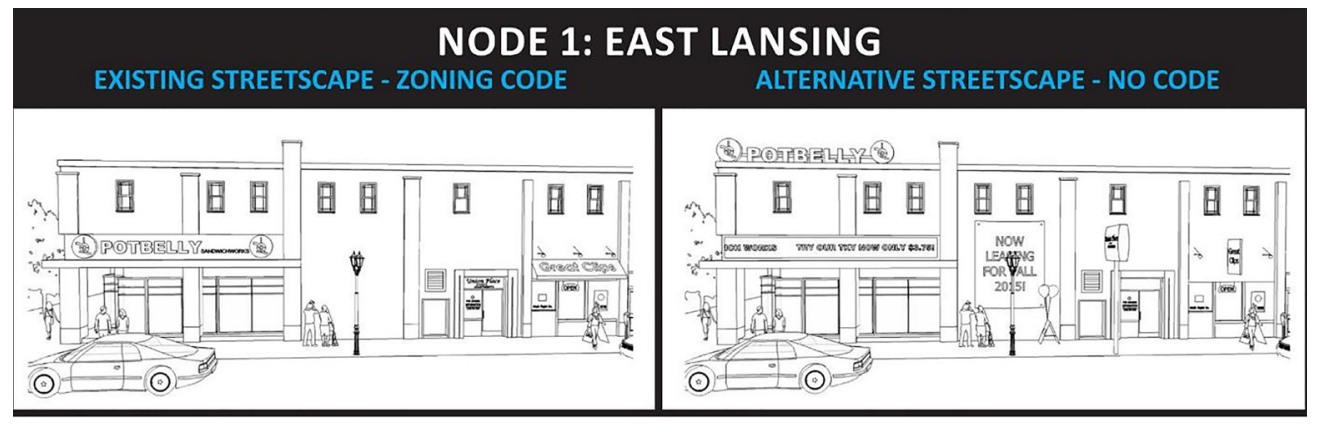

Basis for alternative streetscape model: No Code Sign Application

The sign types added would not be permitted under the existing zoning sign code.

- EMC sign was added to the business called Potbelly.

- Roof sign was added to Potbelly.

- Temporary "Now Leasing" banner was placed, visually filling up the space between Potbelly and Union Place, also giving Union Place more of a presence.

- Sandwich board with balloons was added. Temporary, moving or lit objects, like balloons, would not be permitted under the existing sign code.

- Pole and panel sign was added along the street. This increases visibility along Grand River Avenue. The perpendicular orientation of the sign can be seen from a distance down the street. This sign type in combination with the sign's proximity to the building would not be permitted under the existing sign code.

- Great Clips awning was removed and replaced with a projecting sign, increasing visibility for two-way foot and auto traffic.

\section{Node 2- Lansing East Michigan Avenue}

The signage in Node 2 is governed by the City of Lansing zoning code as an "F-1 parcel" for commercial use. Two streetscape models for Node 2 were created: A zoning code sign model, representative of the existing conditions, and an alternative form-based code sign model (see Figure 7).

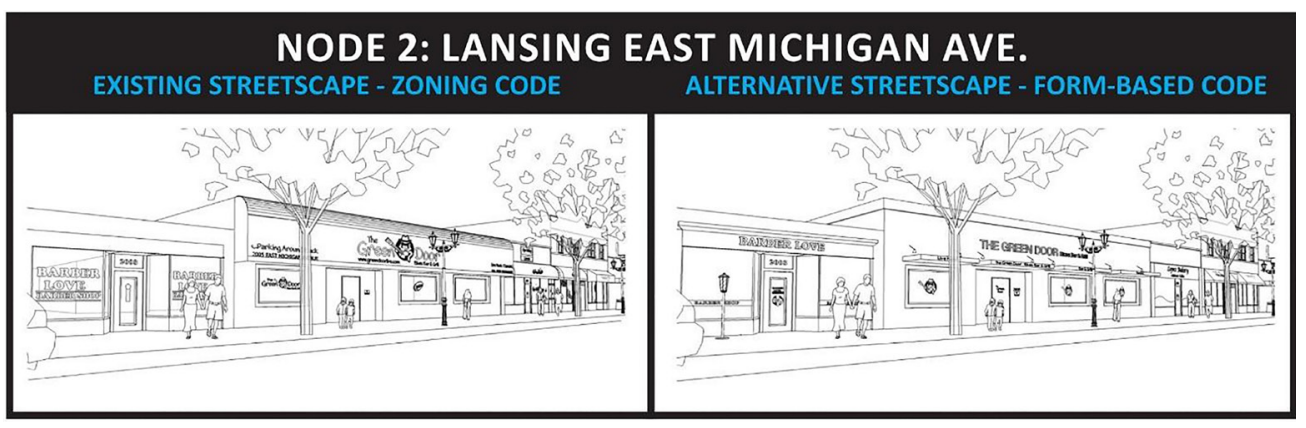

Figure 6 / Node 1: East Lansing Sign Code

Models (Adapted from Crawford et al. (2015))
Figure 7 / Node 2: Lansing East Michigan Avenue Sign Code Models (Adapted from Crawford et al. (2015)). 
Basis for alternative streetscape model: Form-Based Sign Code Application

- Based on Casper's Old Yellowstone District form-based code.

- Awning Signs

$>$ Awnings are limited to first and second floor uses and must project over individual windows and door openings.

$>$ Backlit, translucent, internally illuminated awnings are prohibited.

$>$ Sign or sign lettering shall comprise no more than thirty percent $(30 \%)$ of the total exterior awning surface. Any graphic logo or text printed on an awning is counted toward the allowable sign area.

- Wall Signs

$>$ Wall signs shall not project from the surface upon which they are attached more than twelve (12) inches.

$>$ Wall signs and ghost signs painted directly on a structure are appropriate.

$>$ The maximum total wall signage per façade shall not exceed two (2) square feet per linear foot of building façade length of the wall on which it is located. In no case shall total wall signage exceed three hundred (300) square feet for any building.

- Window Signs

$>$ Window signs shall not cover more than twenty five percent (25\%) of the area of each window.

\section{Node 3-Downtown Lansing}

The signage in Node 3 is zoned as a "G-1 parcel” for business use (Lansing, 2014). Sign regulations are reflective of a model form-based code, serving to preserve vistas, protect the dignity of the area, and enhance the visual cityscape of the Capitol. Two streetscape models for Node 3 were created: A form-based code sign model, representing existing conditions, and an alternative no code sign model (see Figure 8).

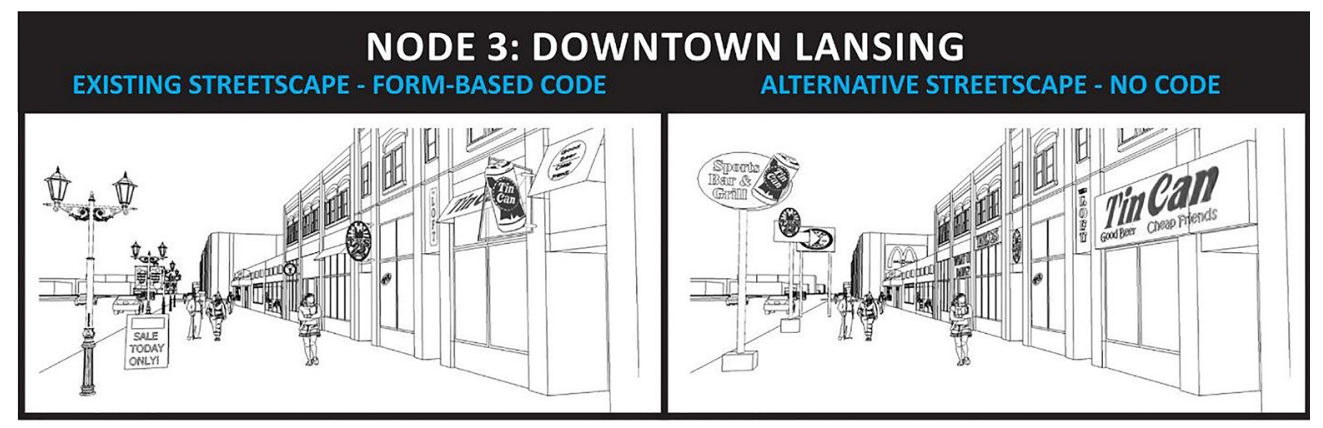

Figure 8 / Node 3: Downtown Lansing Sign Code Models (Adapted from Crawford et al. (2015))

Basis for alternative streetscape model: No Sign Code Application

- Form a generic character, everywhere USA.

- Placement of pole signs along street to attract attention from the heavy 
motor traffic in this area. This sign type in combination with the sign's proximity to the sidewalk would not be permitted under existing sign code.

- Large-scale billboard advertisement placed in the distance. This sign type would not be permitted under existing sign code.

- The awning and projecting signs have been replaced with wall mounted signs, 3D lettering and cabinet signs.

- Increase in the scale of the building-mounted signs to attract attention from motor traffic.

- Enlargement of type size for increased visibility. This text scale would not be permitted under existing sign code.

- Removal of sandwich board.

\section{Perception Indicators}

Beauty, interest, and order were used as indicators to gauge perceptions of the model streetscapes. Identified in previous research studying perceptions of designers and non-designers (Gjerde, 2011; Coeterier, 2002), the indicators of environmental evaluation (Ewing \& Clemente, 2013) and signage perception (Crawford et al., 2015; Portella, 2014; Nasar \& Hong, 1999), have been selected as suitable measures to evaluate perceptions of the sign code model images presented in the survey. In a study of non-designer's perception of historic sites, beauty was studied as a secondary design criterion, and results showed that interest enhanced positive perception (Coeterier, 2002). Research regarding urban environmental evaluation used the concepts of interest and order to measure perception (Nasar \& Hong, 1999; Gjerde, 2011). Gjerde's (2011) research reports that order and visual interest were the two most important factors.

\section{Data Collection}

As a systematic non-experimental design, this study employed the use of an online administered questionnaire, with SurveyMonkey.com as the data collection platform. Because of the low rate of response generally found in online surveys, a snowball effect was used to reach potential participants (Lee, 2014). The survey questionnaire was reviewed and approved by the Michigan State University Institutional Review Board of Human Subject Protection Program (IRB \#14-159).
E-invitations to the survey were distributed through the Signage Foundation Inc. and Michigan State University Land Policy Institute's organizational listservs. Additionally, an announcement with a link to the survey was posted on the Signage Foundation Inc. and the International Sign Association websites, as well as the American Society of Landscape Architects (ASLA), the ASLA Women in Landscape Architecture Professional Practice Network and the Michigan State University Landscape Architecture Club's LinkedIn and Facebook web pages. Other potential participants were contacted electronically through the Environmental Design Research Association, Michigan Avenue Development Authority, Michigan Avenue Homeowners Associations, Michigan State University Center for Community \& Economic Development, and Healthy Home Coalition.

Participants self-identified their user group from a predeveloped list of stakeholder affiliations. Non-designers identified themselves as home, business, or rental property owners, students, developers, institutional and government affiliates, and sign manufacturers. Designers self-identified as professionals in design related fields. Additional demographic identifiers were gathered to determine if the participant group was representative of the general population.

\section{Instruments}

The survey was designed as part of a larger research project, partially funded by the Signage Foundation Inc. The sections of the survey used for this article include a portion on perceptions of model streetscapes with different sign code applications and demographics. The Signage Foundation Inc. review board participated in the questionnaire's vetting process and pre-test. The survey included open and closed-ended questions in the form of multiple choice, interval, semantic differential, and opinion based textual questions. The survey first asked respondents to identify their stakeholder affiliation, followed by ratings of the sign code models, and finally demographic questions.

Pairs of SketchUp models, representing the same streetscape with either a form-based, zoning, or no sign code application, were presented to participants. They were instructed to evaluate the models using five- 
point semantic differential scales that rate the level of beauty, interest, and order. Additionally, open-ended questions about positive and negative characteristics of the signage allowed respondents to elaborate on their perceptions. The pairs of models were randomly presented in the survey to mitigate ordering effects.

The survey gathered demographic responses using predefined multiple-choice answers on the topics of age, gender, major stakeholder affiliation, and education.

\section{Data Analysis}

The data was downloaded from SurveyMonkey in IBM-Statistical Package of SPSS and Microsoft Excel formats. Participant socio-demographic statistics were evaluated through quantitative descriptive statistical analysis. For the five-point semantic differential scales rating perception, a one-way Analysis of Variance (ANOVA) test was used to examine differences in perceptions between designers and non-designers in relation to the indicators beauty, interest, and order. A oneway ANOVA test was used to find differences in perception between designers and non-designers for the form-based, zoning no code sign applications.

\section{RESULTS}

A total of 207 individuals participated in the survey, with $43 \%$ identifying as designers and 54\% as non-designers. Participation across age groups were similar for the designer and non-designer groups with $50 \%$ over $45,30 \%$ in the $30-44$ range, and $20 \%$ between 18 and 29 years old. More women (63\%) participated in the survey than men (37\%).

All participants had some college experience, with 29\% of both the designer and non-designer groups holding a bachelor's degree. The designer group had a higher percentage of participants who held master's (45\%) and doctoral degrees (20\%).

Table 1 / No Code Application - One-Way ANOVA

\begin{tabular}{|l|r|r|r|r|r|r|}
\hline \multicolumn{7}{c|}{ No Code Application - One-Way ANOVA } \\
& Sum of Squares & df & Mean Square & F & Sig. \\
\hline Between Groups & 1.969 & 1 & 1.969 & 6.211 & .014 \\
\hline Within Groups & 51.984 & 164 & .317 & & \\
\hline Total & 53.953 & 165 & & & \\
\hline
\end{tabular}

Table 2 / No Code Application Descriptive Statistics - One-Way ANOVA

\begin{tabular}{|l|r|r|r|r|r|}
\hline \multicolumn{7}{c|}{ No Code Application - Descriptive Statistics } \\
\hline & N & \multicolumn{1}{c|}{ Nean } & Std. Deviation & Std. Error \\
\hline Designers & 71 & 2.6009 & .47432 & .05629 \\
\hline Non-Designers & 95 & 2.8211 & .62088 & .06370 \\
\hline Total & 166 & 2.7269 & .57183 & .04438 \\
\hline
\end{tabular}


Table 3 / Zoning Code Application - One-Way ANOVA

\begin{tabular}{|l|r|r|r|r|r|r|}
\hline \multicolumn{7}{|c|}{ Zoning Code Application - One-Way ANOVA } \\
\hline & Sum of Squares & dif & Mean Square & F & Sig. \\
\hline Between Groups & .484 & 1 & .484 & 2.057 & .153 \\
\hline Within Groups & 37.861 & 161 & .235 & & \\
\hline Total & 38.345 & 162 & & & \\
\hline & Indicates Significant Difference & & \\
\hline
\end{tabular}

Table 4 / Zoning Code Application Descriptive Statistics - One-Way ANOVA

\begin{tabular}{|c|c|c|c|c|}
\hline \multicolumn{5}{|c|}{ Zoning Code Application - Descriptive Statistics } \\
\hline & $\mathbf{N}$ & Mean & Std. Deviation & Std. Error \\
\hline Designers & 70 & 3.2071 & .50476 & .06033 \\
\hline Non-Designers & 93 & 3.3172 & .46952 & .04869 \\
\hline Total & 163 & 3.2699 & .48652 & .03811 \\
\hline
\end{tabular}

Table 5 / Form-Based Code Application - One-Way ANOVA

\begin{tabular}{|l|r|r|r|r|r|r|}
\hline \multicolumn{7}{|c|}{ Form-Based Code Application - One-Way ANOVA } \\
\hline & Sum of Squares & Df & Mean Square & F & Sig. \\
\hline Between Groups & .769 & 1 & .769 & 4.614 & .033 \\
\hline Within Groups & 24.509 & 147 & .167 & & \\
\hline Total & 25.279 & 148 & & \\
\hline
\end{tabular}

Table 6 / Form-Based Code Application Descriptive Statistics - One-Way ANOVA

\begin{tabular}{|l|r|r|r|r|r|}
\multicolumn{5}{|c|}{ Form-Based Code Application - Descriptive Statistics } \\
\hline & $N$ & & Mean & Std. Deviation & Std. Error \\
\hline Designers & 64 & 3.3490 & .41010 & .05126 \\
\hline Non-Designers & 85 & 3.4941 & .40699 & .04414 \\
\hline Total & 149 & 3.4318 & .41328 & .03386 \\
\hline
\end{tabular}

\section{Differences in Code Applications and Designer/Non-designer Perceptions}

To assess the perceptions of designers and non-designers, a one-way ANOVA test compared the combined mean scores of the three aesthetic indicators and three signage zoning application models (see Tables 1-5). Results showed statistically significant differences between designers and non-designers for the no code $(F(1,164)=6.211, p=0.014)$ and for the form-based code applications $(F(1,147)=4.614, p=0.033)$. A significant statistical difference was not found in perceptions regarding the zoning code application $(F(1,161)=2.057, p=$ 0.153). The mean scores displayed in Tables 2,4 , and 6 are on a standard scale, where higher scores indicate more beautiful, more interesting, and more ordered ratings. Lower scores indicate less beautiful, less interesting, and less ordered. Although the mean scores of the designer and non-designer groups were not identical, they were consistent across each code type. For both groups, the formbased code application had the highest aesthetic ranking (Designers $M=3.35$, Non-designers $M=3.49$ ), the zoning code application had the middle ranking (Designers $M=3.21$, Non-designers $M=3.32$ ), and the no code application had 
the bottom ranking (Designers $M=2.60$, Non-designers $M=2.82$ ). The mean scores show that non-designers consistently rated all sign code applications with better aesthetic scores than designers.

\section{Code Applications by Indicator}

The first sub-question asked if a significant difference in perception of beauty, interest, and order in the no code sign models exists between designers and nondesigners (see Table 7). Analysis showed statistically significant differences in the perception of beauty $(F(1,164)=9.395, p=0.003)$ and order $(F(1,164)=4.302$, $p=0.040)$ between the study groups. No statistically significant differences were found regarding the perception of interest $(F(1,164)=0.679, p=0.411)$.

Table 7 / No Code Application and Indicator - One-Way ANOVA

\begin{tabular}{|c|c|c|c|c|c|c|}
\hline \multicolumn{7}{|c|}{ No Code Application and Indicator - One-Way ANOVA } \\
\hline $\begin{array}{l}\text { Code and } \\
\text { Indicator }\end{array}$ & & $\begin{array}{l}\text { Sum of } \\
\text { Squares }\end{array}$ & df & $\begin{array}{l}\text { Mean } \\
\text { Square }\end{array}$ & F & Sig. \\
\hline \multirow[t]{3}{*}{ No Code Beauty } & Between Groups & 3.711 & 1 & 3.711 & 9.395 & .003 \\
\hline & Within Groups & 64.784 & 164 & .395 & & \\
\hline & Total & 68.495 & 165 & & & \\
\hline \multirow[t]{3}{*}{ No Code Interest } & Between Groups & .371 & 1 & .371 & .679 & .411 \\
\hline & Within Groups & 89.637 & 164 & .547 & & \\
\hline & Total & 90.008 & 165 & & & \\
\hline \multirow[t]{4}{*}{ No Code Order } & Between Groups & 2.801 & 1 & 2.801 & 4.302 & .040 \\
\hline & Within Groups & 106.777 & 164 & .651 & & \\
\hline & Total & 109.578 & 165 & & & \\
\hline & \multicolumn{6}{|c|}{ Indicates Significant Difference } \\
\hline
\end{tabular}

The second sub-question tested for significant differences in perception of beauty, interest, and order in the zoning code sign models between designers and nondesigners (see Table 8 ). Statistically significant differences were found in the perception of beauty $(F(1,161)=3.336, p=0.070)$. There were no statistically significant differences between the study groups for the perception of interest $(F(1,161)=0.612, p=0.435)$ and $\operatorname{order}(F(1,160)=0.372, p=0.543)$.

Table 8 / Zoning Code Application and Indicator - One-Way ANOVA

\begin{tabular}{|c|c|c|c|c|c|c|}
\hline \multicolumn{7}{|c|}{ Zoning Code Application and Indicator - One-Way ANOVA } \\
\hline Code and Indicator & & $\begin{array}{l}\text { Sum of } \\
\text { Squares }\end{array}$ & df & $\begin{array}{l}\text { Mean } \\
\text { Square }\end{array}$ & $\mathbf{F}$ & Sig. \\
\hline \multirow[t]{3}{*}{ Zoning Code Beauty } & Between Groups & 1.087 & 1 & 1.087 & 3.336 & .070 \\
\hline & Within Groups & 52.459 & 161 & .326 & & \\
\hline & Total & 53.546 & 162 & & & \\
\hline \multirow[t]{3}{*}{ Zoning Code Interest } & Between Groups & .311 & 1 & .311 & 612 & .435 \\
\hline & Within Groups & 81.879 & 161 & .509 & & \\
\hline & Total & 82.190 & 162 & & & \\
\hline \multirow[t]{4}{*}{ Zoning Code Order } & Between Groups & .123 & 1 & .123 & .372 & .543 \\
\hline & Within Groups & 52.779 & 160 & .330 & & \\
\hline & Total & 52.901 & 161 & & & \\
\hline & \multicolumn{6}{|c|}{ Indicates Significant Difference } \\
\hline
\end{tabular}


The third sub-question tested for significant differences in perception of beauty, interest, and order in the form-based code sign models between designers and non-designers (see Table 9). Statistically significant differences in the perception of beauty $(F(1,147)=6.209, p=.014)$ and interest $(F(1,146)=4.728, p=.031)$ were found, but there was no statistically significant difference for the perception of order $(F(1,147)=0.109, p=0.742)$.

Table 9 / Form-Based Code Application and Indicator - One-Way ANOVA

\begin{tabular}{|c|c|c|c|c|c|c|}
\hline \multicolumn{7}{|c|}{ Form-Based Code Application and Indicator - One-Way ANOVA } \\
\hline Code and Indicator & & $\begin{array}{r}\text { Sum of } \\
\text { Squares }\end{array}$ & df & $\begin{array}{r}\text { Mean } \\
\text { Square }\end{array}$ & F & Sig. \\
\hline \multirow[t]{3}{*}{$\begin{array}{l}\text { Form-Based Code } \\
\text { Beauty }\end{array}$} & $\begin{array}{l}\text { Between } \\
\text { Groups }\end{array}$ & 1.805 & 1 & 1.805 & 6.209 & .014 \\
\hline & Within Groups & 42.732 & 147 & .291 & & \\
\hline & Total & 44.537 & 148 & & & \\
\hline \multirow[t]{3}{*}{$\begin{array}{l}\text { Form-Based Code } \\
\text { Interest }\end{array}$} & $\begin{array}{l}\text { Between } \\
\text { Groups }\end{array}$ & 1.945 & 1 & 1.945 & 4.728 & .031 \\
\hline & Within Groups & 60.062 & 146 & .411 & & \\
\hline & Total & 62.007 & 147 & & & \\
\hline \multirow[t]{4}{*}{ Form-Based Code Order } & $\begin{array}{l}\text { Between } \\
\text { Groups }\end{array}$ & .025 & 1 & .025 & .109 & .742 \\
\hline & Within Groups & 34.277 & 147 & .233 & & \\
\hline & Total & 34.302 & 148 & & & \\
\hline & Indicates Signi & ifference & & & & \\
\hline
\end{tabular}

\section{Mean Comparisons}

The mean scores displayed in Tables 10, 11, and 12 are on a standard scale, where higher scores indicate more beautiful, more interesting, and more ordered ratings. Designers rated the form-based code application as the most beautiful $(M=3.20)$ and most ordered $(M=3.77)$, and the zoning code application as most interesting $(M=3.12)$. Non-designers rated the form-based code application as the most beautiful $(M=3.42)$, interesting $(M=3.31)$, and ordered $(M=3.75)$. Both groups rated the no code application as the least beautiful (Designers $M=2.37$, Non-designers $M=2.67$ ), least interesting (Designers $M=2.77$, Nondesigners $M=2.86$ ), and least ordered (Designers $M=2.67$, Non-designers $M=2.93$ ).

Table 10 / No Code Application \& Indicator - Descriptive Statistics for One-Way ANOVA

\begin{tabular}{|l|l|r|r|r|r|}
\multicolumn{5}{c}{ No Code Application and Indicator - Descriptive Statistics } \\
\hline \multirow{2}{*}{ Indicator } & N & Mean & Std. Deviation & Std. Error \\
\hline Beauty & Designer & 71 & 2.3662 & .58528 & .06946 \\
\hline & Non-Designer & 95 & 2.6684 & .65886 & .06760 \\
\hline & Total & 166 & 2.5392 & .64430 & .05001 \\
\hline \multirow{2}{*}{ Interest } & Designer & 71 & 2.7676 & .69092 & .08200 \\
\hline & Non-Designer & 95 & 2.8632 & .77337 & .07935 \\
\hline \multirow{2}{*}{ Order } & Total & 166 & 2.8223 & .73858 & .05732 \\
\hline & Designer & 71 & 2.6690 & .77434 & .09190 \\
\hline & Non-Designer & 95 & 2.9316 & .83031 & .08519 \\
\hline & Total & 166 & 2.8193 & .81493 & .06325 \\
\hline
\end{tabular}


Table 11 / Zoning Code Application \& Indicator - Descriptive Statistics for One-Way ANOVA

\begin{tabular}{|c|c|c|c|c|c|}
\hline \multicolumn{6}{|c|}{ Zoning Code Application and Indicator - Descriptive Statistics } \\
\hline Indicator & & $\mathbf{N}$ & Mean & Std. Deviation & Std. Error \\
\hline \multirow[t]{3}{*}{ Beauty } & Designer & 70 & 3.0286 & .60724 & .07258 \\
\hline & Non-Designer & 93 & 3.1935 & .54190 & .05619 \\
\hline & Total & 163 & 3.1227 & .57492 & .04503 \\
\hline \multirow[t]{3}{*}{ Interest } & Designer & 70 & 3.1214 & .70421 & .08417 \\
\hline & Non-Designer & 93 & 3.2097 & .71976 & .07464 \\
\hline & Total & 163 & 3.1718 & .71228 & .05579 \\
\hline \multirow[t]{3}{*}{ Order } & Designer & 69 & 3.4928 & .62716 & .07550 \\
\hline & Non-Designer & 93 & 3.5484 & .53194 & .05516 \\
\hline & Total & 162 & 3.5247 & .57322 & .04504 \\
\hline
\end{tabular}

Table 12 / Form-Based Code Application \& Indicator - Descriptive Statistics for One-Way ANOVA

\begin{tabular}{|l|l|r|r|r|r|}
\multicolumn{5}{c}{ Form-Based Code Application and Indicator - Descriptive Statistics } \\
\hline \multirow{2}{*}{ Indicator } & \multicolumn{2}{c}{ N } & Mean & Std. Deviation & Std. Error \\
\hline Beauty & Designer & 64 & 3.1953 & .56073 & .07009 \\
\hline & Non-Designer & 85 & 3.4176 & .52240 & .05666 \\
\hline \multirow{2}{*}{ Interest } & Total & 149 & 3.3221 & .54857 & .04494 \\
\hline & Designer & 64 & 3.0781 & .63132 & .07891 \\
\hline & Non-Designer & 84 & 3.3095 & .64893 & .07080 \\
\hline Order & Total & 148 & 3.2095 & .64947 & .05339 \\
\hline & Designer & 64 & 3.7734 & .50340 & .06292 \\
\hline & Non-Designer & 85 & 3.7471 & .46690 & .05064 \\
\hline & Total & 149 & 3.7584 & .48143 & .03944 \\
\hline
\end{tabular}

\section{DISCUSSION}

The results show that there are, in fact, perception differences of on-premise commercial sign regulations between designers and non-designers and highlight similarities as well. Significant differences were found in both the no code $(F(1$, $164)=6.211, p=0.014)$ and the form-based code applications $(F(1,147)=4.614$, $p=0.033)$. The three code types structurally vary the organization of signage. The zoning code application $(F(1,161)=2.057, p=0.153)$, which was not found to be perceived differently between the study groups, is the median in modern structural signage organization. The no and form-based code applications are on opposite ends of the spectrum, represented by the chaos of having no codes and rigid design structure of form-based codes. Greater differences in perception between designers and non-designers were identified between these two codes. Historically, zoning codes have been the most prevalent type of sign regulation in the United States (Liebermann, 2002), so familiarity with this organizational style could contribute to the common perceptions amongst designers and nondesigners around this model.

Similarities between these two groups became apparent when analyzing the mean scores of the form-based, zoning, and no code applications. Although there are statistically significant differences between the study groups, the mean scores show that each of the code applications were ranked in the same order consistently 
between designers and non-designers. The no code application for designers (Designers $M=2.60$, Non-designers $M=2.82$ ) had the lowest mean score, meaning that it was perceived as the least beautiful, interesting, and ordered. The zoning code application (Designers $M=3.21$, Non-designers $M=3.32$ ) had the median score, followed by the form-based code application (Designers $M=3.35$, Non-designers $M=3.49$ ), implying that it was perceived as the most beautiful, interesting, and ordered. This indicates that designers and non-designers both perceive similar aesthetics in the sign code models, however participants with design background consistently rated each indicator more harshly than their counterparts.

\section{Beauty, Interest, and Order}

The familiar proverb, beauty is in the eye of the beholder, expresses the diverse nature of the perception of beauty. Beauty was the only variable to have a statistically significant difference between designers and non-designers over all the code applications. Order and interest were perceived as significantly different between study groups, indicating that these characteristics are more universally understood or evaluated. These findings relate to previous research, where Gjerde (2011) specifically identified order and interest as the primary factors that influence environmental aesthetic perception. Beauty may be the variable in which professional training in planning and design influences perception.

This study validates that when rating signscapes, measures of interest and order can be useful tools in developing sign controls. Because of their more universal perception, these factors may be more accurately represented in signage codes. Due to significant differences in perceptions between groups, beauty becomes a variable that requires greater attention in early stages of public planning and participation in order to accurately represent the needs and desires of the public.

\section{Perception \& Communication}

The designer and non-designer groups evaluated the model sign codes in a consistent order, however there were significant differences in the strength of rating given to the indicators in the form-based and no code sign applications. Those with a design background consistently rated each indicator more harshly, indicating that designers' professional and educational backgrounds may provide them with the confidence to make stronger convictions about sign code models.

\section{CONCLUSION \\ Principal Conclusions}

Six conclusions emerged from the survey analysis:

1. There is a significant difference in the perception of on-premise commercial sign regulations between designers and non-designers on signscapes represented by the form-based and no sign code applications, the most and least structurally organized regulations. There are not statistically significant differences regarding the zoning code application, likely because of its median structural organization and prevalence in current American signscapes.

2. There are similarities in perception of onpremise commercial sign regulations between designers and non-designers on which sign code application produced the most beautiful, interesting, and ordered streetscape. The form-based code had the best aesthetic score, while the zoning code had the median aesthetic score, and the no code was least favored. This was consistent between both study groups, regardless of statistically significant differences found in the formbased and no sign code applications.

3. Significant differences were produced from the degree to which designers and non-designers ranked the indicators beauty, interest, and order. Designers tended to give lower scores than non-designers, but the order in which the study groups ranked the model streetscapes was consistent for each code type.

4. Beauty was the only indicator to have a statistically significant difference between the designer and non-designer groups for all of the streetscape models. The indicators order and interest were more similarly rated across the sign models, suggesting that beauty is perceived differently than the indicators of order and interest between designers and nondesigners. 
5. The mean scores for which signscape was ranked as the least beautiful, interesting, and ordered indicate harsher ratings by designers than non-designers.

6. Because of the consistency of mean scores, the results suggest that designers do not perceive the model sign codes much differently than non-designers, but that they are simply more critical with their evaluations, which led to statistically significant differences in the form-based and no code model streetscapes.

\section{Limitations and Future Research}

Studies like this are a starting point for exploring designers and non-designers' perceptions of sign regulation. To accurately represent perceptions of signage over time, this type of research will need to be repeated to keep up with changing perceptions and signage technology. A convenience snowball sampling strategy was used in this study which limits the generalizability of the findings; it should also be noted that participants were shown software generated black and white line-drawings not the actual sign in real-world conditions with varying lighting, color, and other sensory conditions that affect perception. Finally, while this study focused on environmental designers and urbanists, future work should include graphic designers as a stakeholder group, given the role that they play in signage development.

\section{Implications}

By understanding differences in communication and evaluation of on-premise commercial sign regulations, designers can more effectively coordinate with the public to create well received sign codes. This research shows both commonalities and differences between designers and non-designers, suggesting that professionals within the planning and design realm cannot assume they entirely understand the wants and needs of the community for whom they are designing. In particular, the perception of beauty is an area where these differences are most apparent. Because this characteristic is not mutually understood, professionals should closely consider the input of the public regarding their perception of beauty when designing sign regulations.
This study shows that designers tend be more critical in their judgment of commercial sign regulation than non-designers, a trait that could hinder collaboration between designers and community partners. In order to improve communication, designers should consider listening to public perceptions and ideas prior to formulating and presenting much of their own thoughts.

Sign codes influence the physical characteristics and placement of commercial signs, impacting the visual quality of a streetscape. This research confirms that people appreciate the structure of a sign code provides, regardless of professional planning or design training. Implications of these findings show that regulation for signage is justified, as it contributes to a more positively viewed and functional streetscapes, which aids in the production of a thriving public realm. 


\section{REFERENCES}

Alford, H. C. (2011). Impact of Signage on Economic Development and the Need for Commonsense Zoning Laws and Regulations (SFI Research Report). Washington DC: The Signage Foundation, Inc.

American Society of Landscape Architects. (2016). About the American society of landscape architects. https://www.asla.org/ FAQAnswer.aspx?CategoryTitle= About the American Society of Landscape Architects\&Category=3146\#DispID3116

Bai, Y., Finger, K., \& Yue, L. (2010). Analyzing motorists' responses to temporary signage in highway work zones. Safety Science, 48(2), 215-221. doi: 10.1016/j.ssci.2009.08.005

Berger, C. (2014). Signs and the downtown experience (SFI Research Report). Washington DC: The Signage Foundation, Inc.

Burisch, M. (1979). Expert and lay opinion in the evaluation of housing. In: J. G. Simon(Ed.) Conflicting Experiences of Space: 25-34. http://iaps.architexturez.net/doc/oai-iaps.id-iaps_00_1979_1_001

City Data. (2012). East Lansing, Michigan [Data File]. http://www.city- data.com/city/East-Lansing-Michigan.html

City of Lansing, Lansing Planning Office. (2012). Design Lansing Comprehensive Plan.

Coeterier, J. F. (2002). Lay people’s evaluation of historic sites. Landscape and Urban Planning, 59(2), 111-123. doi:10.1016/ S0169-2046(02)00007-5

Cohen, D. T., Harchard G. W., \& Wilson, S. G. (2015, March). Population trends in incorporated places: 2000 to 2013. https:// www.census.gov/content/dam/Census/library/publications/2015/demo/p25- 1142.pdf

Crawford, P., Lee, E. \& Beatty, M. (2015). Aesthetic perception of urban streetscapes and the impact of form-based codes and traditional zoning codes on commercial signage. Current Urban Studies, 3, 199-215. doi: 10.4236/cus.2015.33017

Creighton, J. L. (2005). The Public Participation Handbook: Making Better Decisions Through Citizen Involvement. San Francisco: Jossey-Bass

East Lansing. (2014). Code of ordinances-part II chapter 32 signs. East Lansing, MI: Planning Department.

Ewing, R. H. \& Clemente, O. (2013). Measuring Urban Design: Metrics for Livable Places.

Washington, D.C.: Island Press.

Form-Based Codes Institute Staff. (2013, November 22). History. https://formbasedcodes.org/

Garvey, P., Crawford, B. (2015). On-premise Sign Research Review (SFI Research Report).Washington DC: The Signage Foundation, Inc.

Gjerde, M. (2011). Visual evaluation of urban streetscapes: How do public preferences reconcile with those held by experts? Urban Design International, 16(3), 153-161.

Jourdan, D., Hurd, K., Hawkins, H. G., \& Winson-Geideman, K. (2013, Spring). Evidence-based sign regulation: Regulating signage on the basis of empirical wisdom. The Urban Lawyer, 45(2), 327.

Kaplan, S. \& Kaplan, R. (1989). The visual environment: Public participation in design and planning. Journal of Social Issues, 45, 59-86.

Kieffer, S. (2001). Glossary of Signage Terms (SFI Research Report). Washington DC: The Signage Foundation, Inc.

Kinoshita, Y. \& Orlando, C. C. (2013). Art of signage: The regulation of outdoor murals and the first amendment. Cardozo Law Review, 35(1), 867-896.

Lane, M. B. (2005). Public participation in planning: An intellectual history. Australian Geographer, 36(3), 283-299.

Lansing. (2014). Code of ordinances, part 14-building and housing code title 4-miscellaneous building regulations chapter 1442signs. Lansing, MI: Planning Department.

Lee, E. (2014, November). Quantitative Method. Lansing: Michigan State University.

Liebermann, G. W. (2002). Modernization of zoning: A means to reform. The Appraisal Journal, 7(2), 224-229.

Meikle, J. L. (2013). Signs, streets, and storefronts: A history of architecture and graphics along America's commercial corridors. Technology and Culture, 54(3), 672-674.

Nasar, J. L. \& Hong, X. (1999). Visual preference in urban signscapes. Environment and Behavior, 32(5), 671-691.

Parolek, D., Parolek, K., \& Crawford, P. (2008). Form-Based Codes: A Guide for Planners, Urban Designers, Municipalities, and Developers. New Jersey: John Wiley \& Sons Inc.

Partin, S. (2011). SketchUp Validity Modeling: A Comparison Between Photographs and 3D Models (Master's Thesis). ProQuest Dissertations \& Theses Global. (Access No. 915789183). 
Pendlebury, J. \& Townshend, T. (1999). The conservation of historic areas and public participation. Journal of Architectural Conservation, 5(2), 72-87.

Portella, A. (2014). Visual Pollution: Advertising, Signage and Environmental Quality. Burlington: Ahsgate Publishing Limited.

Pugalis, L. (2009). The culture and economics of urban public space design: Public and professional perceptions. Urban Design International, 14(4), 215-230.

Rexhausen, J., Hildebrandt, G. \& Auffrey, C. (2012). The Economic Value of On-premise Signage (SFI Research Report). Washington DC: The Signage Foundation, Inc.

Sanoff, H. (2000). Community Participation Methods in Design and Planning. New York: Wiley.

Stotmeister, E. (2013, October). Economic Value of On-premise Signage (EVOS): A Story of Research 1997 - 2012 (SFI Research Report). Washington DC: The Signage Foundation, Inc.

Strauss, E. J., Jourdan, D., \& Weinstein, A. (2014). Basic Sign Law for Planning Students (SFI Research Report). Washington DC: The Signage Foundation, Inc.

Taylor, C. R. (2006). How excessive restrictions on signage backfire. The Journal of Consumer Marketing, 23(2), 56-57.

Taylor, C. R. (2011). Value Provided by On-Premise Signs: Measuring the Economic Value to the Business Enterprise (SFI Research Report). Washington DC: The Signage Foundation, Inc.

Taylor, C. R., Sarkees, M. E., \& Bang, H. (2012). Understanding the value of on-premise signs as marketing devices for legal and public policy purposes. Journal of Public Policy \& Marketing, 31(2), 185-194.

United States Department of Agriculture. (2015). Shifting Geography of Population Change. Washington DC: Economic Research Service.

Vandebona, U. \& Yossayaffra. (1999). Analysis of signage requirements for pedestrian movements. Road \& Transport Research, 8(4),55.

Werner, R. E. \& Kaminoff, R. D. (1983). Improving environmental information: Effects of signs on perceived crowding and behavior. Environment and Behavior, 15(1), 3-20.

Witter, S. \& Crawford, P. (2013). Creating a World Class Community. East Lansing, MI: School of Planning, Design \& Construction, Michigan State University.

Yung, H. K. \& Chan, H. W. (2013). Evaluation for the conservation of historic buildings: Differences between the laymen, professionals and policy makers. Facilities, 31(11/12), 542-564. 


\section{APPENDICES}

CUS (http://www.scirp.org/journal/cus/)

\section{Permission Letter}

Dear Maleah Beatty,

Thanks for your contribution to Current Urban Studies (CUS).Your paper:

Paper ID: 1150135

Paper Title: Aesthetic Perception of Urban Streetscapes and the Impact of Form-Based Codes and Traditional Zoning Codes on Commercial Signage.

Authors: Pat Crawford, Eunsil Lee, Maleah Beatty

has been published and released online

(http://www.scirp.org/journal/PaperInformation.aspx?PaperID=59321).

The DOI is $10.4236 /$ cus.2015.33017.

The author retains the copyright of the above paper, which allows you to (noncommercially) copy, use, distribute, transmit and display the work publicly and to make and distribute derivative works, in any digital medium for any responsible purpose, subject to proper attribution of authorship.

Best wishes

CUS Editorial Officanumumumu,

E-mail: cus@scispos

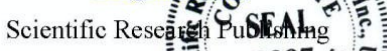

http://www.scir $=0.007 \%$

LAW

"m, *m..............."

Appendix A / Permission of Copyright from the Journal of Current Urban Studies

* note: Maleah Rakestraw's maiden name is Maleah Beatty 